\title{
Flow-Mediated Dilatation and Asymmetric Dimethylarginine Do Not Predict Mortality in Peritoneal Dialysis Patients
}

\section{Akım Aracılı Dilatasyon ve Asimetrik Dimetilargi Periton Diyalizi Hastalarında Mortalite Prediktörü Değildir}

\author{
Sami Uzun, Serhat Karadağ, Meltem Gürsu*, Egemen Cebeci, Ahmet Gürdal**, Tuba Elif \\ Şenel, Ayça Eroğlu, Savaş Öztürk \\ University of Health Sciences Haseki Training and Research Hospital, Clinic of Nephrology, Istanbul, Turkey \\ *Bezmialem Vakıf University Faculty of Medicine, Department of Nephrology, Istanbul, Turkey \\ **istanbul University Istanbul Faculty of Medicine, Department of Cardiology, Istanbul, Turkey
}

\section{Abstract}

Aim: Asymmetric dimethylarginine (ADMA) is associated with increased coronary artery disease risk through endothelial dysfunction in dialysis patients. We aimed to investigate the role of flow-mediated dilatation (FMD), a non-invasive indicator of endothelial function, and ADMA in mortality in peritoneal dialysis (PD) patients.

Methods: PD patients aged 18-80 years; with dialysis duration of at least three months were included. FMD measurement and ADMA levels were recorded. Outcome of the patients on the third year were analyzed with binary logistic analyses.

Results: The mean age of the 55 patients was $53 \pm 15$ years and the mean follow-up duration was 36 months. Mean FMD and ADMA levels were $10.6 \pm 6.4 \%$ and $81.8 \pm 48.0 \mathrm{~mol} / \mathrm{L}$, respectively. Eighteen patients died during follow-up. Age, presence of diabetes mellitus and ischemic heart disease, ultrafiltration amount and serum albumin level were related with mortality while gender, weekly Kt/ $\mathrm{V}$ and ADMA levels were not. There was no significant relationship between ADMA level and FMD ( $p=0.873)$. FMD was negatively correlated with systolic and diastolic blood pressures ( $p=0.001, p<0.001$, respectively). Hypertension was found to be the most important single factor determining FMD ( $p=0.037)$.

Conclusion: Estimating endothelial function by FMD or measuring serum ADMA levels may not be useful for predicting mortality in PD patients.

Keywords: Flow mediated dilatation, asymmetric dimethylarginine, endothelial dysfunction, peritoneal dialysis, mortality
Amaç: Diyaliz hastalarında asimetrik dimetilarginin (ADMA) endotel disfonksiyonu yoluyla artmış koroner arter hastalığı riski ile ilişkilidir. Bu çalışmada periton diyalizi (PD) hastalarında endotel disfonksiyonunun non-invaziv bir göstergesi olan akım aracılı dilatasyon (AAD) ve ADMA'nın mortalite ile ilişkisini araştırmayı amaçladık.

Yöntemler: Çalışmaya 18-80 yaş aralı̆ı̆ıda, en az üç aydır diyaliz uygulanan PD hastaları dahil edildi. AAD ölçümü ve ADMA düzeyleri kaydedildi. Üçüncü yılda hasta sonlanımlarında "binary lojistik analizi" kullanıldı.

Bulgular: Çalışmaya dahil edilen 55 hastanın yaş ortalaması $53 \pm 15$ yll, ortalama takip süresi 36 ay idi. Ortalama $A A D$ ve $A D M A$ düzeyleri sırasıyla \%10,6 $\pm 6,4$ ve $81,8 \pm 48,0 \mathrm{~mol} / \mathrm{L}$ idi. On sekiz hasta takip sırasında öldü. Yaş, diyabet ve iskemik kalp hastalığı varlığı, ultrafiltrasyon miktarı ve serum albümin düzeyleri mortalite ile ilişkili iken cinsiyet, haftalık Kt/V ve ADMA düzeyleri ilişkili değildi. ADMA düzeyleri ve $A A D$ arasında anlamlı ilişki yoktu $(p=0,873)$. AAD ile klinik parametrelerden sistolik ve diastolik kan basıncı arasında anlamlı negatif korelasyon vardı $(p=0,001, p<0,001)$. Tüm parametreler arasında $A A D^{\prime} y i$ belirleyen en önemli tek faktör hipertansiyondu ( $p=0,037)$.

Sonuç: AAD ile endotel fonksiyonunun değerlendirilmesi veya serum ADMA düzeylerinin ölçülmesi periton diyalizi hastalarında mortaliteyi tahmin etmek için yararlı olmayabilir.

Anahtar Sözcükler: Akım aracılı dilatasyon, asimetrik dimetilarginin, endotel disfonksiyonu, periton diyalizi, mortalite
Address for Correspondence/Yazışma Adresi: Sami Uzun

University of Health Sciences Haseki Training and Research Hospital, Clinic of Nephrology, İstanbul, Turkey

Phone: +90 2125294400 E-mail: drsamiuzun@gmail.com ORCID ID: orcid.org/0000-0002-7843-164x Received/Geliş Tarihi: 23 December 2016 Accepted/Kabul Tarihi: 25 December 2016
${ }^{\circ}$ Copyright 2017 by The Medical Bulletin of University of Health Sciences Haseki Training and Research Hospital
The Medical Bulletin of Haseki published by Galenos Yayinevi.

Telif Hakkı 2017 Sağlık Bilimleri Üniversitesi Haseki Eğitim ve Araştırma Hastanesi Haseki Tıp Bülteni, Galenos Yayınevi tarafından basıımıștı. 


\section{Introduction}

Despite the progress in dialysis treatments, the most important cause of mortality in end-stage renal disease (ESRD) patients is still cardiovascular diseases (CVD) $(1,2)$. Multiple complex mechanisms increase the risk for cardiovascular events in ESRD. Endothelial dysfunction is the beginning of atherosclerosis process leading to CVD. Evidence for endothelial dysfunction in renal disease patients mainly relies on measurements of circulating biomarkers $(3,4)$ and in vivo assessment of endothelial function in larger vessels (5). Asymmetric dimethylarginine (ADMA) is an endogenous amino acid, formed by methylation of arginine in vascular endothelial cells (6). Although it is metabolized mainly in the liver, its circulating level is elevated in uremic patients. ADMA is a potent inhibitor of nitric oxide synthesis. Hence, it is accepted as a cardiovascular risk factor by causing endothelial dysfunction (7). ADMA levels have been shown to be increased in different patient populations including in those with diabetes mellitus (DM), coronary heart disease, renal impairment, hypertension (HT), hypercholesterolemia, and hyperhomocysteinemia (812). Impairment of endothelium-dependent vasodilation is defined as endothelial dysfunction and brachial artery flow-mediated dilation (FMD) is a widely used non-invasive method for testing endothelial function (13).

There are a limited number of studies evaluating ADMAendothelial dysfunction interplay in peritoneal dialysis (PD) patients with conflicting results. Although there are few studies on the relationship between endothelial dysfunction and atherosclerotic process in PD patients (14), there is no study evaluating the effect on mortality of ADMA levels and FMD, and the relationship between these two parameters in PD patients who have increased risk for cardiovascular complications. We have previously studied the relationship between ADMA levels and cardiac functions in PD patients (15). We aimed in the present study to investigate the relationship of ADMA levels and endothelial functions with mortality in PD patients in the same cohort.

\section{Methods}

\section{Patients}

The study population is the same with our study published previously. Fifty-five PD patients with a dialysis duration longer than three months, who were followed up in our outpatient unit, were included. Patients who did not give informed consent, those younger than 18 or older than 80 years, patients with dialysis duration less than three months, valvular heart disease, dysrhythmias, heart failure (NYHA class 3 or 4), clinically evident hypervolemia, active systemic infection, active malignancy and history of peritonitis within the last month were excluded from the study. According to the local criterion, the study did not necessitate ethics committee approval due to the design of the study which did not include any invasive procedures or drug use.

Age, gender, body mass index (BMI), renal disease causing renal failure, duration of chronic kidney disease and $\mathrm{PD}$, comorbidities, and the medications prescribed were recorded. Blood pressure was measured after 12 hours of fasting for cigarette, caffeine and beverages containing alcohol, and at least ten minutes of rest. Patients were recorded as having ischemic heart disease (IHD) if they had a positive past medical history, clinical signs or electrocardiographic findings.

\section{Laboratory Methods}

Blood samples were taken after an overnight fasting of 8-12 hours for measurement of glucose, urea, creatinine, sodium, potassium, uric acid, cholesterol, triglyceride, alanine transaminase, aspartate transaminase, calcium, phosphorus, parathyroid hormone (PTH), total protein, albumin, leukocyte, hemoglobin, hematocrit, ferritin, highsensitive C-reactive protein (hsCRP), and ADMA levels.

Biochemical analysis and hematological tests were performed using a Siemens Advia 2400 auto analyzer and ABX Pentra DX120 machine, respectively. Intact PTH and ferritin levels were analyzed by the Advia Centaur ${ }^{\circledR} \mathrm{XP}$ system and the hsCRP levels with Advia $2400^{\circledR}$ machine.

Serum samples for ADMA measurement were kept frozen at $-80^{\circ} \mathrm{C}$ until analysis performed by competitive enzyme-linked immunosorbent assay (ELISA) method using Cusabio Biotech CO. LTD, Human ADMA ELISA Kit.

Standard peritoneal equilibration test was performed for measurement of $\mathrm{Kt} / \mathrm{V}$, urea and creatinine clearances. A residual urine volume of $200 \mathrm{~mL}$ or more was regarded as significant. Total daily fluid removal was calculated for each patient by adding daily urine volume to ultrafiltration volume.

\section{Flow Mediated Dilation}

FMD of the brachial artery was evaluated in PD group only by ultrasonographic method using Vingmed System Five, (GE Vingmed AS, Horten, Norway) linked to a 10 $\mathrm{MHz}$ linear transducer. Measurements were done after at least ten minutes of rest and 8-12 hours of fasting at $21-23^{\circ} \mathrm{C}$ temperature. The patients did not consume any beverages containing alcohol or caffeine for 12 hours before the study. The inner diameter of the brachial artery of the non-dominant arm was measured with the patient in the supine position followed by five minutes of 200 $\mathrm{mmHg}$ pressure applied by sphygmomanometer to induce ischemia in the forearm. The measurement was repeated sixty seconds after deflation of the sphygmomanometer. 
FMD was calculated by the formula [(diameter after deflation-basal diameter)/basal diameter) x 100].

The outcome of the patients (still on PD, death, transplantation, transfer to hemodialysis, transfer to another center) was recorded after three years of followup.

\section{Statistical Analysis}

Statistical analysis was carried on by Statistical Package for Social Sciences (SPSS) for Windows 15.0 standard version. Numerical parameters were expressed as mean \pm standard deviation. Student's paired t-test or the MannWhitney $U$ test was used for comparison of two groups. Pearson's and Spearman's rho correlation coefficients were used for correlation analysis of numerical and nonnumerical parameters, respectively. A $p$ value of less than 0.05 or $95 \%$ confidence interval was considered statistically significant. Factors affecting the levels of ADMA and FMD variables were analyzed by linear regression analysis (Backward method). Three-year survival analysis was performed by binary logistic regression analysis. Age, gender, PD duration, presence of DM, IHD, ultrafiltration volume, Kt/V and albumin levels besides ADMA and FMD were analyzed in the model.

\section{Results}

Fifty-five PD patients fulfilling the inclusion criteria who were followed up in our outpatient unit were included. The mean age and male/female ratio of the patients were $53 \pm 15$ years and $24 / 31$, respectively. The mean PD duration was $40.6 \pm 25$ months. The dialysis modality was continuous ambulatory PD in $63.3 \%(n=35)$, automated PD in $32.1 \%(n=17)$ and hybrid regimes in $5.7 \%(n=3)$. DM was the most common cause of ESRD (30.9\%). HT was the most common comorbidity (78.2\%). Primary kidney diseases, major comorbidities and the medications prescribed are presented in Table 1. Eleven patients had $I H D$, and five of them were hypertensive. Twelve patients were on ASA treatment due to IHD $(n=9)$ or with the aim of primary prophylaxis $(n=3)$ for IHD.

The mean BMI was $27.7 \pm 6.5 \mathrm{~kg} / \mathrm{m}^{2}$. Mean systolic, diastolic and mean blood pressures were 129.3 \pm 21.3 $\mathrm{mmHg}, \quad 80.1 \pm 10.6 \mathrm{mmHg}$ and $96.6 \pm 13.7 \mathrm{mmHg}$, respectively (Table 1).

The laboratory data of the patients are presented in Table 2. Mean Kt/V and daily urine output were $2.49 \pm 0.65$ and $800 \pm 784 \mathrm{~mL} /$ day, respectively. The mean weekly residual and dialysate creatinine clearance and the mean ultrafiltration volume were $33 \pm 32 \mathrm{~mL} /$ week, $45 \pm 12 \mathrm{~mL} /$ week and $931 \pm 619 \mathrm{~mL} /$ day, respectively.

The mean FMD and ADMA levels were determined as $10.6 \pm 6.4 \%$ and $81.8 \pm 48.0 \mu \mathrm{mol} / \mathrm{L}$, respectively. There was no statistically significant correlation between ADMA and FMD ( $r=-0.025, p=0.873)$. Patients with HT had significantly lower FMD levels compared to those without (9.01 \pm 5.79 vs. $14.89 \pm 6.63, p=0.012)$. Similarly, diabetic patients had lower FMD than nondiabetics $(7.73 \pm 4.01$ vs. $11.74 \pm 6.98, p=0.022$ ). There was no relationship of FMD with other comorbidities and the etiology of ESRD. None of the laboratory parameters studied was correlated with FMD. FMD was not statistically correlated with PDrelated parameters, including total, residual and dialysate $\mathrm{Kt} / \mathrm{V}$, residual and dialysate urea, and creatinin clearance. The medications that the patients used (renin-angiotensin aldosterone system blockers, beta blockers, calcium channel blockers, acetylsalicylic acid, statins) were not related with FMD, neither.

The variables with an alpha significance level below 0.10 in univariate analysis (systolic and diastolic blood pressure, presence of $\mathrm{HT}$, DM) were analyzed with

\begin{tabular}{|c|c|c|}
\hline \multicolumn{3}{|c|}{ Table 1. Baseline demographic data of the patients } \\
\hline \multicolumn{2}{|c|}{ Parameter } & $\begin{array}{l}\text { Mean } \pm \text { standard } \\
\text { deviation }\end{array}$ \\
\hline \multicolumn{2}{|c|}{ Age (years) } & $53 \pm 15$ \\
\hline \multicolumn{2}{|c|}{ Gender (female/male) } & $31 / 24$ \\
\hline \multicolumn{2}{|r|}{ Duration of chronic kidney disease (years) } & $7.1 \pm 4.6$ \\
\hline \multicolumn{2}{|c|}{ Peritoneal dialysis duration (months) } & $40.6 \pm 25.0$ \\
\hline \multicolumn{2}{|c|}{ Diabetes mellitus ( $n, \%)$} & $17(30.9)$ \\
\hline \multicolumn{2}{|c|}{ Hypertension (n, \%) } & $43(78.2)$ \\
\hline \multicolumn{2}{|c|}{ Ischemic heart disease ( $n, \%)$} & $11(20)$ \\
\hline \multicolumn{2}{|c|}{ Hyperlipidemia (n, \%) } & $23(41.8)$ \\
\hline \multirow{7}{*}{ 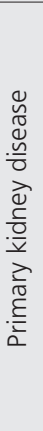 } & Hypertensive nephrosclerosis ( $\mathrm{n}, \%)$ & $8(14.5)$ \\
\hline & Diabetic nephropathy (n, \%) & $16(29.1)$ \\
\hline & Unknown (n, \%) & $14(25.5)$ \\
\hline & Glomerulonephritis ( $\mathrm{n}, \%)$ & $6(10.9)$ \\
\hline & Chronic pyelonephritis ( $\mathrm{n}, \%)$ & $5(9.1)$ \\
\hline & $\operatorname{ADPKD}(n, \%)$ & $3(5.5)$ \\
\hline & VUR nephropathy (n, \%) & $3(5.5)$ \\
\hline \multicolumn{2}{|c|}{ Weight (kg) } & $71.5 \pm 16.4$ \\
\hline \multicolumn{2}{|c|}{ Body mass index $\left(\mathrm{kg} / \mathrm{m}^{2}\right)$} & $27.7 \pm 6.5$ \\
\hline \multicolumn{2}{|c|}{ Systolic blood pressure $(\mathrm{mmHg})$} & $129.3 \pm 21.3$ \\
\hline \multicolumn{2}{|c|}{ Diastolic blood pressure $(\mathrm{mmHg})$} & $80.1 \pm 10.6$ \\
\hline \multicolumn{2}{|c|}{ Mean blood pressure $(\mathrm{mmHg})$} & $96.6 \pm 13.7$ \\
\hline
\end{tabular}


multivariate analysis in which HT was found to be single most important factor determining FMD $(B=-5.37$, Beta $=-$ $0.379, p=0.010$ ). Age and gender did not have any effect when added to the model.

Survival analysis was performed at the end of three years. Eighteen patients $(32.7 \%)$ died due to any reason. Another 18 patients $(32.7 \%)$ were lost to follow-up because of renal transplantation or transfer to hemodialysis. One patient was transferred to another center, while the remaining 18 patients $(32.7 \%)$ are still being followed up in our unit. The patients were grouped according to the median levels of ADMA and FMD. The subgroups had similar survival rates when compared by a chi-square test $(p=0.63$ and $p=0.50$, respectively). The parameters found by binary logistic regression analysis to be related with three-year mortality were age, presence of DM and IHD, total daily fluid removal, serum albumin level; while gender, total weekly Kt/V, FMD and ADMA did not have any effect on survival (Table 3 ).

\section{Discussion}

Endothelial dysfunction is an early feature in the development of vascular complications, responsible for majority of mortality and morbidity. In the present study, we investigated associations of endothelial functions with FMD in PD patients who are at high risk for CVD. The presented study did not detect any correlation between FMD and ADMA which was shown to cause endothelial damage in different population of patients. There are many studies showing concordance between ADMA levels and endothelial dysfunction in non-uremic patients (16-19). It is known that ADMA level increases as renal functions decrease reaching very high levels in case of ESRD (20). However, there are conflicting results regarding the effect of elevated ADMA level on endothelial function. No correlation was detected in two studies in which ADMA and FMD were studied in PD patients $(21,22)$. Kielstein et al. (21) carried on the first study on this subject. They evaluated in their controlled study the relationship between ADMA and atherosclerotic disease in hemodialysis (HD) and PD patients. PD patients had similar ADMA levels with the control group, while HD patients had significantly higher ADMA levels that were related to atherosclerotic disease. The difference between this study and the others was that ADMA levels in PD patients were not higher than in healthy control subjects (20). In a controlled study by Kocak et al. (22), nondiabetic PD patients with no atherosclerotic disease had higher ADMA levels than control subjects, but there was no relationship between ADMA and endothelial dysfunction. Diabetic patients and those with CVD were also included in our study. In another study, PD patients were found to have higher ADMA levels than controls, but endothelial dysfunction in these patients could not be explained by this increased level (23). Many mechanisms are known to be effective on endothelial dysfunction in uremic patients, increased ADMA level being only one of them (24). There are concordant and discordant results in larger broadbased studies carried on HD patients (21-25). The reason for lack of evidence for correlation in patients with ESRD having many comorbidities, while the evidence is stronger in non-uremic patients with lower cardiovascular risk, may be coexistence of many cardiovascular risk factors (26). The absence of this correlation in our study population may also be due to the presence of many cardiovascular risk factors. The frequency of comorbidities that are also risk factors for CVD (DM, HT, IHD, hyperlipidemia) were substantially high (Table 1).

Moreover, diabetic and hypertensive patients in our study population had significantly lower FMD. The relationship with DM disappeared in multivariate analysis while that with HT remained independent from age and

\begin{tabular}{|c|c|}
\hline Parameter & $\begin{array}{l}\text { Mean } \pm \\
\text { standard } \\
\text { deviation }\end{array}$ \\
\hline Glucose (mg/dL) & $136 \pm 80$ \\
\hline Urea (mg/dL) & $100 \pm 34$ \\
\hline Uric acid (mg/dL) & $6.1 \pm 1.0$ \\
\hline Sodium (mmol/L) & $137 \pm 4$ \\
\hline Potassium (mmol/L) & $4.1 \pm 0.6$ \\
\hline Aspartate transaminase $(\mathrm{U} / \mathrm{L})$ & $19 \pm 18$ \\
\hline Alanine transaminase $(\mathrm{U} / \mathrm{L})$ & $17 \pm 10$ \\
\hline Alkaline phosphatase $(U / L)$ & $134 \pm 191$ \\
\hline Gamma glutamyl transferase (U/L) & $30 \pm 49$ \\
\hline Calcium (mg/dL) & $9.0 \pm 0.6$ \\
\hline Phosphorus (mg/dL) & $5.0 \pm 1.2$ \\
\hline Calcium $\times$ Phosphorus $(\mathrm{mg} / \mathrm{dL})^{2}$ & $45 \pm 12$ \\
\hline Total protein $(\mathrm{g} / \mathrm{dL})$ & $6.5 \pm 0.7$ \\
\hline Albumin (g/dL) & $3.74 \pm 0.39$ \\
\hline High sensitive C-reactive protein (mg/dL) & $2.0 \pm 4.2$ \\
\hline Iron ( $\mu \mathrm{gr} / \mathrm{dL})$ & $66 \pm 23$ \\
\hline Total iron binding capacity ( $\mu \mathrm{gr} / \mathrm{dL})$ & $247 \pm 35$ \\
\hline Triglyceride (mg/dL) & $170 \pm 93$ \\
\hline Total cholesterol (mg/dL) & $189 \pm 44$ \\
\hline HDL cholesterol (mg/dL) & $42 \pm 16$ \\
\hline WBC $(/ \mathrm{mL})$ & $8365 \pm 2643$ \\
\hline Hematocrit (\%) & $32.6 \pm 4.1$ \\
\hline Hemoglobin (g/dL) & $10.8 \pm 1.4$ \\
\hline
\end{tabular}


gender. These findings may be interpreted as endothelial dysfunction in our study population was independent from ADMA level. Similarly, Philpott et al. (27) showed in their study with non-uremic subjects that FMD was related only with HT among cardiovascular risk factors; while endothelial dysfunction was shown to be related with other risk factors by methods other than FMD.

Studies performed with non-uremic population show that the effect of multiple traditional cardiovascular risk factors on indirect findings of endothelial dysfunction may be different from the effect seen with each one separately. In a recent study by Mizia-Stec et al. (28) carried on with 617 non-uremic patients, it was shown that patients without cardiovascular risk factors had higher FMD; and those with more than one cardiovascular risk factor did not have an additional decrease in FMD compared to patients with only one risk factor. Other studies also support the hypothesis that FMD is a valuable test for endothelial dysfunction, but loses its power as the number of cardiovascular risk factors increases $(26,29)$. This may explain the persistent relationship between HT and FMD in multivariate analysis while the effect of DM disappeared.

Neither FMD nor ADMA were found to be related with mortality analyzed at the end of the third year. Only age, presence of DM and IHD, ultrafiltration volume and serum albumin level were found to affect survival (Table 2). The association of FMD with increased risk of cardiovascular

\begin{tabular}{|c|c|c|c|c|c|}
\hline & & \multirow[t]{2}{*}{ p } & \multirow[t]{2}{*}{ OR } & \multicolumn{2}{|c|}{$95 \% \mathrm{Cl}$ for $\mathrm{OR}$} \\
\hline & & & & Lower & Upper \\
\hline \multicolumn{2}{|c|}{ Constant } & 0.111 & 1738880 & & \\
\hline \multicolumn{2}{|c|}{ Diabetes mellitus } & 0.017 & 39.225 & 1.903 & 808.675 \\
\hline \multicolumn{2}{|c|}{ Serum albumin } & 0.016 & 0.003 & 0.000 & 0.338 \\
\hline \multicolumn{2}{|c|}{ Age } & 0.043 & 1.133 & 1.004 & 1.278 \\
\hline \multicolumn{2}{|c|}{ Gender } & 0.891 & 1.156 & 0.147 & 9.116 \\
\hline \multicolumn{2}{|c|}{ FMD } & 0.303 & 3.249 & 0.344 & 30.640 \\
\hline \multicolumn{2}{|c|}{ ADMA } & 0.189 & 0.167 & 0.011 & 2.419 \\
\hline \multicolumn{2}{|c|}{ Total fluid removal } & 0.104 & 1.002 & 1.000 & 1.005 \\
\hline \multicolumn{2}{|c|}{$\begin{array}{l}\text { Ischemic heart } \\
\text { disease }\end{array}$} & 0.118 & 0.079 & 0.003 & 1.910 \\
\hline \multicolumn{2}{|c|}{ Total Kt/Vurea } & 0.224 & 0.192 & 0.013 & 2.746 \\
\hline \multirow{4}{*}{ 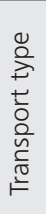 } & High & 0.321 & & & \\
\hline & High average & 0.408 & 0.266 & 0.012 & 6.121 \\
\hline & Low average & 0.941 & 1.140 & 0.036 & 36.063 \\
\hline & Low & 0.241 & 44.097 & 0.079 & 24630.341 \\
\hline
\end{tabular}

FMD: Flow-mediated dilatation, ADMA: Asymmetric dimethylarginine, Cl: Confidence interval, OR: Odds ratio events in patients at risk is well known (30). Besides, uremia is known to cause endothelial dysfunction and increase cardiovascular risk (31). However, there are no recent studies about the effect of endothelial dysfunction in PD patients except that by Lee et al. (14) who studied with PD patients without DM and other cardiovascular risk factors. They reported that FMD was related to major cardiovascular events during 42 months of follow up. The exclusion of patients with DM and other risk factors provides homogeneity, but the population in this study was not the prototype for PD patients faced by physicians in clinics. DM is the leading cause of ESRD, and about half of PD patients have impaired fasting glycaemia due to the glucose content of dialysis solutions. Thus, inclusion of diabetic subjects may provide more realistic data about risk-survival analysis of PD patients (32). The presence of DM and IHD among the factors effective on survival in our study (Table 3) supports this idea.

We did not find any relationship between serum ADMA level and mortality in both univariate and multivariate analyses. Although there are a limited number of studies about the effect of ADMA on survival of PD patients, it is not surprise not to find a relationship between ADMA and mortality as ADMA-endothelial dysfunction interaction was not shown by two previous studies and our study. Moreover, it is interesting that the presence of DM is a prognostic factor although not related with ADMA level and FMD.

Similarly, albumin level is a stronger prognostic factor for mortality than FMD and ADMA in our study. Serum albumin level has been known as a strong predictor of mortality in PD patients (33).

Hypervolemia is an important predictor of morbidity and mortality in PD patients (34). On the other hand, we did not find a correlation of endothelial dysfunction with residual renal functions, total fluid removal, and dialysis adequacy parameters. The reason for this finding may be the exclusion of patients with clinically overt hypervolemia. There are a limited number of studies in the literature about the relationship between residual functions and endothelial dysfunction. Han et al. (35) reported that endothelial function was preserved with preserved renal functions. On the other hand, ADMA levels in patients with preserved residual renal functions were found to be lower compared to that in PD patients with lost residual functions and in HD patients (36). We did not find a relationship between residual renal functions and ADMA.

There are some limitations of our study. Lack of a control group and low number of patients prevent a more reasonable interpretation of our findings. However, in contrast to non-uremic subjects, the number of studies and the number of PD patients in studies in the literature 
are already low all over the world. Another shortcoming of the study is lack of information about death individually and also non-fatal cardiovascular events. In spite of these factors, our study can be the one leading to more broad based studies as it is one of the first studies evaluating the relationship between FMD and ADMA.

\section{Conclusion}

Estimating endothelial function by FMD or measuring serum ADMA levels may not be useful for predicting mortality in PD patients.

\section{Ethics}

Ethics Committee Approval: It was not taken.

Informed Consent: It was taken.

Peer-review: Internally peer-reviewed.

\section{Authorship Contributions}

Surgical and Medical Practices: S.U., S.K., A.G. Concept: S.Ö. Design: S.Ö., M.G. Data Collection or Processing: E.C., T.E.Ş., A.E. Analysis or Interpretation: S.U., S.Ö. Literature Search: S.U. Writing: S.U.

Conflict of Interest: No conflict of interest was declared by the authors.

Financial Disclosure: The authors declared that this study received no financial support.

\section{References}

1. Collins AJ, Li S, Ma JZ, Herzog C. Cardiovascular disease in end-stage renal disease patients. Am J Kidney Dis 2001;38(4 Suppl 1):26-9.

2. Parfrey PS. Cardiac and cerebrovascular disease in chronic uremia. Am J Kidney Dis 1993;21:77-80.

3. Yilmaz MI, Saglam M, Caglar K, et al. The determinants of endothelial dysfunction in CKD: oxidative stress and asymmetric dimethylarginine. Am J Kidney Dis 2006;47:4250.

4. Felmeden DC, Lip GY. Endothelial function and its assessment. Expert Opin Investig Drugs 2005;14:1319-36.

5. Ghiadoni L, Versari D, Giannarelli C, Faita F, Taddei S. Noninvasive diagnostic tools for investigating endothelial dysfunction. Curr Pharm Des 2008;14:3715-22.

6. Moncada S, Palmer RM, Higgs EA. Biosynthesis of nitric oxide from L-arginine: A pathway for the regulation of cell function and communication. Biochem Pharmacol 1989;38:1709-15.

7. Böger RH. The emerging role of asymmetric dimethylarginine as a novel cardiovascular risk factor. Cardiovasc Res 2003;59:824-33.

8. Kawano H, Motoyama T, Hirashima O, et al. Hyperglycemia rapidly suppresses flow-mediated endothelium-dependent vasodilation of brachial artery. J Am Coll Cardiol 1999;34:14654.

9. Miyazaki H, Matsuoka H, Cooke JP, et al. Endogenous nitric oxide synthase inhibitor: a novel marker of atherosclerosis. Circulation 1999;99:1141-6.
10. Zoccali C, Bode-Böger S, Mallamaci $F$ et al. Plasma concentration of asymmetrical dimethylarginine and mortality in patients with end-stage renal disease: a prospective study. Lancet 2001;358:2113-7.

11. Böger RH, Bode-Böger SM, Szuba A, et al. Asymmetric dimethylarginine (ADMA): a novel risk factor for endothelial dysfunction: its role in hypercholesterolemia. Circulation 1998;98:1842-7.

12. Dayal S, Lentz SR. ADMA and hyperhomocysteinemia. VasC Med 2005;10(Suppl 1):27-33.

13. Celermajer DS, Sorensen KE, Gooch VM, et al. Non-invasive detection of endothelial dysfunction in children and adults at risk of atherosclerosis. Lancet 1992;340:1111-5.

14. Lee MJ, Han SH, Lee JE, et al. Endothelial dysfunction is associated with major adverse cardiovascular events in peritoneal dialysis patients. Medicine (Baltimore) 2014;93:e73.

15. Ozturk S, Karadag S, Yegen M, et al. The relationship of plasma ADMA levels with cardiac functions and metabolic parameters in peritoneal dialysis patients. Clin Exp Nephrol 2013;17:431-6.

16. Henry RM, Ferreira I, Kostense PJ, et al. Type 2 diabetes is associated with impaired endothelium-dependent, flowmediated dilation, but impaired glucose metabolism is not; The Hoorn Study. Atherosclerosis 2004;174:49-56.

17. Panza JA, Quyyumi AA, Brush JE Jr, Epstein SE. Abnormal endothelium-dependent vascular relaxation in patients with essential hypertension. N Engl J Med 1990;323:22-7.

18. Clarkson P, Celermajer DS, Powe AJ, Donald AE, Henry RM, Deanfield JE. Endothelium-dependent dilatation is impaired in young healthy subjects with a family history of premature coronary disease. Circulation 1997;96:3378-83.

19. Norata GD, Grigore L, Raselli S, et al. Post-prandial endothelial dysfunction in hypertriglyceridemic subjects: molecular mechanisms and gene expression studies. Atherosclerosis 2007;193:321-7.

20. Kielstein JT, Böger RH, Bode-Böger SM, et al. Marked increase of asymmetric dimethylarginine in patients with incipient primary chronic renal disease. J Am Soc Nephrol 2002;13:1706.

21. Kielstein JT, Böger RH, Bode-Böger SM, et al. Asymmetric dimethylarginine plasma concentrations differ in patients with end-stage renal disease: relationship to treatment method and atherosclerotic disease. J Am Soc Nephrol 1999;10:594600.

22. Kocak H, Gumuslu S, Sahin E, et al. Advanced oxidative protein products are independently associated with endothelial function in peritoneal dialysis patients. Nephrology (Carlton) 2009;14:273-80.

23. Mittermayer F, Schaller G, Pleiner J, et al. Asymmetrical dimethylarginine plasma concentrations are related to basal nitric oxide release but not endothelium-dependent vasodilation of resistance arteries in peritoneal dialysis patients. J Am Soc Nephrol 2005;16:1832-8. 
24. Brunet $P$, Gondouin B, Duval-Sabatier A, et al. Does uremia cause vascular dysfunction? Kidney Blood Press Res 2011;34:284-90.

25. Kumagai $H$, Sakurai $M$, Takita $T$, et al. Association of homocysteine and asymmetric dimethylarginine with atherosclerosis and cardiovascular events in maintenance hemodialysis patients. Am J Kidney Dis 2006;48:797-805.

26. Witte DR, Westerink J, de Koning EJ, van der Graaf Y, Grobbee DE, Bots ML. Is the association between flowmediated dilation and cardiovascular risk limited to low-risk populations? J Am Coll Cardiol 2005;45:1987-93.

27. Philpott AC, Lonn E, Title LM, et al. Comparison of new measures of vascular function to flow mediated dilatation as a measure of cardiovascular risk factors. Am J Cardiol 2009;103:1610-5.

28. Mizia-Stec K, Wieczorek J, Orszulak M, et al. Flow-mediated dilatation (FMD) and prevalence of cardiovascular risk factors - the value of FMD assessment in high risk patients is limited. Kardiol Pol 2014;72:254-61.

29. Tomiyama H, Matsumoto C, Yamada J, et al. The relationships of cardiovascular disease risk factors to flow-mediated dilatation in Japanese subjects free of cardiovascular disease. Hypertens Res 2008;31:2019-25.
30. Ras RT, Streppel MT, Draijer R, Zock PL. Flow-mediated dilation and cardiovascular risk prediction: a systematic review with meta-analysis. Int J Cardiol 2013;16:344-51.

31. Go AS, Chertow GM, Fan D, McCulloch CE, Hsu CY. Chronic kidney disease and the risks of death, cardiovascular events, and hospitalization. N Engl J Med 2008;18:4.

32. Szeto CC, Chow KM, Kwan BC, Chung KY, Leung CB, Li PK. New-onset hyperglycemia in nondiabetic chinese patients started on peritoneal dialysis. Am J Kidney Dis 2007;49:52432.

33. Rocco MV, Jordan JR, Burkart JM. The efficacy number as a predictor of morbidity and mortality in peritoneal dialysis patients. J Am Soc Nephrol 1993;4:1184-91.

34. Ateş K, Nergizoğlu G, Keven K, et al. Effect of fluid and sodium removal on mortality in peritoneal dialysis patients. Kidney Int 2001;60:767-76.

35. Han SH, Lee SC, Kang EW, et al. Reduced residual renal function is associated with endothelial dysfunction in patients receiving peritoneal dialysis. Perit Dial Int 2012;32:149-58.

36. Eiselt J, Rajdl D, Racek J, Siroká R, Trefil L, Opatrná S. Asymmetric dimethylarginine in hemodialysis, hemodiafiltration, and peritoneal dialysis. Artif Organs 2010;34:420-5. 